\title{
THE CLASH OF PROPERTY AND ENVIRONMENTAL RIGHTS IN THE NIGER DELTA REGION OF NIGERIA
}

\author{
Sunday Bontur Lugard*
}

\begin{abstract}
The Niger Delta region of Nigeria, home to about 30 million people, is one of the world's most prominent deltas. Petroleum exploration in this region has been ongoing for over fifty years and revenue from this activity is at present the mainstay of the Nigerian economy. Granted that it is impracticable to undertake petroleum operations without some negative impact on the environment, a good deal of this pollution can be mitigated. The International Oil Companies (IOCs) are complacent about pollution reduction to a sustainable level; regulatory agencies are either compromised or lack the required expertise or equipment to monitor and enforce compliance with extant environmental protection laws and regulations. The pursuit of the IOCs' property right over petroleum resources has set them against the other stakeholders' right to a healthy environment. The clash of these rights can best be addressed by ascribing "collective property" and not "private property" right to the acreage over which they have been granted licence to prospect for, explore or mine petroleum resources.
\end{abstract}

Keywords: Property rights, natural resource exploration, environmental law.

doi: http://dx.doi.org/10.4314/jsdlp.v6i2.3

\section{INTRODUCTION}

In Nigeria, ownership right over extractive natural resources is an exclusive preserve of the federal government. ${ }^{1}$ Apart from the Constitution, the Petroleum Act $^{2}$ re-enacts in unmistakable terms the exclusive power of the federal

* Lecturer, Department of International Law and Jurisprudence, Faculty of Law, University of Jos, Nigeria; lugards@unijos.edu.ng.

1 Section 43 of the Constitution of the Federal Republic of Nigeria 1999 (as amended).

2 Cap. P10, Laws of the Federation of Nigeria, 2004. 
government over petroleum and other natural resources found within the geographical entity called Nigeria. ${ }^{3}$ The federal government in the exercise of its ownership "right" over such resources usually grants or leases such right to commercial entities, especially International Oil Companies (IOCs) to explore (by way of oil operations) the advantages of such rights and share the accruing benefits through several operational regimes ranging from concessions to production sharing contracts, service contracts and joint venture agreements.

The IOCs, being de facto holders of rights over petroleum resources leased to them by the government, usually focus on the exploration of the advantages of such rights to the extent that the consequential anthropogenic degradation of the environment and its impact on the other stakeholders is not given a prominent consideration. This, therefore, results in contest between the oil companies and the host communities, being the most visible burden-bearer in the event of environmental pollution. While the oil companies lay claim to the right to exploit and explore the natural resources, the communities are zealous about environmental protection and sustainability, among other claims.

This paper considers the conflicting interests of the mining and exploration rights of IOCs over hydrocarbons in the region and the impact of such activities on the human environment and human rights of the inhabitants of the region. The question here is, does the right to mine also extend to the right to pollute?

\section{PROPERTY OWNERSHIP IN HISTORICAL PERSPECTIVE}

There are basically three categories of property ownership: common property, collective property (including state ownership), and private property. ${ }^{4}$

3 The State was further defined in section 15 of the Act to mean the Federal Government.

4 J. Waldron, "What is Private Property?" (1985) 5 OJLS 313, 333, quoted in C Rodgers, 'Nature's Place? Property Rights, Property Rules and Environmental Stewardship' (2009) 68(3) Cambridge Law Journal, 552; J. Waldron, "Property and Ownership" in EN Zalta (ed.) The Stanford Encyclopaedia of Philosophy (Spring 2012 Edition) < http://plato.stanford.edu/archives/spr2012/entries/ property/> accessed 31 March 2016; G Hardin, Nature and Man's Fate (Holt, Rinehart and Winston New York (1959) quoted in P. Barnes, Capitalism 3.0: A Guide to Reclaiming the Commons (Berrett-Koehler Pub., Tennessee - USA 2006) preface, x; GD Libecap, "Property Rights in Economic History: Implications for Research" (1986) 23 Explorations in Economic History 235. He classifies them as collective, private and state-owned. 
The common ${ }^{5}$ property system operates on the premise that resources are governed by rules whose point is to make them available for use by all or any member of the society. ${ }^{6}$ It is communally owned and outsiders may not always be allowed to encroach on such resources. A portion of land, for instance, may be reserved for every member of a community for grazing cattle in an agrarian society. Similarly, a park may be open to all for picnics, sports or some form of recreation. The aim of any restrictions on use is simply to secure fair access for all and to prevent anyone from using the common resource in a way that would preclude its use by others. ${ }^{7}$ Its major contrast with private property is in its inclusive rather than exclusive nature or access to use. ${ }^{8}$

Common property ownership, without doubt, preceded the private property ownership structure that pervades the society today. In the beginning, "the commons" was everywhere. Humans and other animals roamed around it, hunting and gathering. Like other species of mammals, men had territories that were considered the exclusive property of a tribe, but not individuals. About ten thousand years ago, however, human agriculture and permanent settlements (sedentary lifestyle) began to evolve, and with that came the need for private property ownership. ${ }^{9}$ Rulers granted ownership of land to heads of families (usually males, whose descendants inherited same under the primogeniture system). In the same vein, military conquerors distributed land to their lieutenants. Titles were then passed on to the oldest sons of the initial beneficiaries' subordinates (as inheritance). ${ }^{10}$

5 The common property (the commons) has for a long time been under threat from profitable human activities. A philosophy, "tragedy of the commons" as popularised by Garrett Hardin postulates that people will always overuse the commons when it is in their self-interest. Peter Barnes has posited that the commons is not made in reference to grazing land as most people are wont to assume, but that it refers to all the gifts we inherit or create together: they are all gifts (something we receive and not earn - and a shared gift is one we receive as members of a community, as opposed to individually). See P. Barnes (n 4) preface, $x$.

6 E. N. Zalta, ed., The Stanford Encyclopaedia of Philosophy (Spring 2012 Edition) <http://plato.stanford.edu/entries/property/\#4> accessed 28 June 2012. See also R Heltberg 'Property Rights and Natural Resource Management in Developing Countries' (2002) 16 (2) Journal of Economic Surveys, 193.

7 J. Waldron (n 4).

8 P. Barnes (n 4) 6.

9 ibid 15.

10 ibid. 
The Roman law codified many of these systems or practices. In medieval Roman times, bodies of water, shorelines, wildlife, and air were explicitly classified as res communes, resources available to all. Personal claims to ownership of natural resources like rivers, forests, and wild animals by kings and feudal lords during the Middle Ages, were basically rejected. ${ }^{11}$

Collective property is another form of property ownership. Here, the community as a whole determines how important resources are to be used. These determinations were made on the basis of the social interest through mechanisms of collective decision-making, for instance, a leisurely debate among the elders of a tribe. ${ }^{12}$ Some are governed by collective property rules (e.g., military bases and artillery pieces). Also, the interest of a right-holder of such property is not absolute; it is subject to overriding public interest over how such property is used by its owner (an owner's freedom is restricted by rules regulating the use of same). ${ }^{13}$ More to the point are things like zoning restrictions, which amount in effect to the imposition of a collective decision about certain aspects of the use of a given resource. For example, the right of a building owner in a historic district may include restriction imposed on demolition of the building with a view to erecting a modern structure.${ }^{14}$ In this case, one can assert that the historic building is doubtlessly a private property; but if too many other areas of decision about its use were also controlled by public agencies, one would be more inclined to conclude that it is subject to a collective property rule (with the "owner" operating as steward of society's decisions). ${ }^{15}$ This restriction, though short of expropriation, makes private property subject to the collective property rule.

Private property, on the other hand, is entirely different from the above types. Property rules are organised around the idea that various resources are assigned to the discretional power of particular individuals (or families or firms). ${ }^{16}$ The right of a proprietor is not extinguished because of the impact of the way in which he uses his property. An owner of a steel factory, for instance, is at liberty to decide whether to close it or to keep the plant operating, even though a decision to close may have the gravest impact on its employees and on the prosperity of the local community. ${ }^{17}$

11 ibid 15-16.

$12<$ http://wiki.mises.org/wiki/Property> accessed 2 July 2012.

13 ibid.

14 ibid.

15 ibid.

16 P Barnes (n 4) 16.

17 ibid. 
Legally speaking, property or ownership right connotes a complete and total right over a property. The owner of the property is not subject to the right of another person. Because he is the owner, he has the full and final right of alienation or disposition of the property, and he exercises this right of alienation and disposition without seeking the consent of another party because as a matter of law and fact there is no other party's right over the property that is higher than his. ${ }^{18}$

Private property is usually acquired through outright purchase, conquest, inheritance or lease (wherein the lessee acquires an equitable interest that can be extinguished by the expiration of the term granted). The biblical account of creation is also instructive here; it shows that God gave man the power over all created things, tangible and intangible: God said, "Let us make man in our image ... let them have dominion over the fish of the sea, over the birds of the air, and over the cattle, over all the earth and over every creeping thing that creeps on the earth" ... [and to] "Be fruitful and multiply; fill the earth and subdue it..."19

This history of mankind presents no need for property ownership, as there was no contest between Adam and Eve, on the one part, and another person over any of the mentioned natural property. They possessed the right to proper use of all created things subject to the overriding instruction of God, the creator. The natural resources were not "owned", either jointly or severally, by them. This kind of possessory right can at best be equated with common ownership.

The Bible further shows a genealogy of the first man and the subsequent destruction of mankind, ${ }^{20}$ but Noah alongside his family survived the great destruction. However, the biblical narration makes no reference to private property and inheritance until Chapter 13 of Genesis where Abram (later rechristened Abraham) was said to have owned livestock. The increase in number made individual ownership of some resources inevitable, hence the need for inheritance, buying and selling of property, particularly, land. ${ }^{21}$ This biblical account shows a shift from common to collective and then private ownership of property, which evolved with demographic changes.

18 Per Niki Tobi in Abraham \& Anor. v. Olorunfunmi \& Ors (1991) 1 NWLR (Pt.165) 53.

19 Genesis Chap. 1 verses 26 to 28, The Holy Bible, New King James Version, (Thomas Nelson Inc., Tennessee USA 1982).

20 ibid chapter 5.

21 Abraham was buried on the piece of land he purchased from the sons of Heth Chapter 25 verses 9 and 10 of Genesis. 


\section{WHAT ARE PROPERTY RIGHTS?}

It has been asserted "[A] property right is the exclusive authority to determine how a resource is used, whether that resource is owned by government, collective bodies, or by individuals." ${ }^{22}$ Private property refers to a kind of system that allocates particular objects like pieces of land to particular individuals to use and manage as they please, to the exclusion of others (even others who have a greater need for the resources) and to the exclusion also of any detailed control by society. ${ }^{23}$

Similarly, a lawyer considers property right as "entrenched in the Constitution of every civilised society, as immutable, inviolable right." 24 According to the predominant view, if person X holds a "right" to something, at least one other person must have a corresponding duty not to interfere with X's possession and use of such a thing. If X claims a "right", but cannot point to a corresponding "duty" that is enforceable against at least one other person, then what X possesses may not be a "right" at all but some lesser entitlement such as a privilege, liberty, or mere use. ${ }^{25}$

Private law sprang up to regulate inter-personal relations among men in the society because of the inevitability of clash of rights or interests in the cause of human interaction. And where those clashes are experienced, whose interest prevails and what forms the bases for one interest, prevailing over the other?

An interesting case in sight is the early twentieth century case of Madison v. Ducktown Sulphur, Copper \& Iron Co Ltd., ${ }^{26}$ where such an interesting clash of rights came before the Tennessee Supreme Court (in the United States of America) for determination in 1904. It was a case of nuisance where the plaintiffs, owners of small farmlands, sought perpetual injunctive reliefs against the defendants for operating their plants near Ducktown in Polk County. The

22 A. A. Alchian, "Property Rights" The Concise Encyclopaedia of Economics (2nd Edn) </www.econlib. org/library/Enc/PropertyRights.html> accessed 1 June 2012. The writer further posits that, "Society approves the uses selected by the holder of the property right with governmental administered force and with social ostracism. If the resource is owned by the government, the agent who determines its use has to operate under a set of rules determined, in the United States, by Congress or by executive agencies it has charged with that role."

23 E. N. Zalta (ed.) (n 6)

24 O. Oliyide, "Theoretical Basis for Private Property Rights: Some Reflections" (2011) 1 (1) BIU Law Journal, 452.

25 D. H. Cole and P. Z. Grossman (n 21).

2683 S.W. 658, 666-67 (1904). 
plants emitted thick smoke from their "roast piles" which descended upon the surrounding lands, and injured trees and crops, and rendered the homes of plaintiffs less comfortable and their lands less profitable than before. The assessed cumulative value of the lands of the plaintiffs was about US\$700, while the plants were assessed at over US\$2,000,000.

The plaintiffs complained of loss of value of their timber, destruction of their customary crops and discomfort to family members. The complainant proved through uncontroverted evidence that the smoke made his wife to cough from time to time and had made his crops to shed their yield; hence it would be impracticable for him to sustain his family in the area if the activities of the defendants were not halted. The court in its final judgement declined to uphold the injunctive relief granted by the trial court but granted them damages:

The question now to be considered is, what is the proper exercise of discretion, under the facts appearing in the present case? Shall the complainants be granted, in the way of damages, the full measure of relief to which their injuries entitle them, or shall we go further, and grant their request to blot out two great mining and manufacturing enterprises, destroy half of the taxable values of a county, and drive more than 10,000 people from their homes? We think there can be no doubt as to what the true answer to this question should be.

In order to protect by injunction several small tracts of land, aggregating in value less than US $\$ 1,000$, we are asked to destroy other property worth nearly US $\$ 2,000,000$, and wreck two great mining and manufacturing enterprises. ${ }^{27}$

The interesting issue about this judgement is whether the economic value attached to business undertaking is enough reason for continuous infringement on the right of others and whether, going by the court's judgement, the right to recover damages on a continuous basis had been conferred on the plaintiffs against the defendants. It is like telling the poor owner of the contiguous land to go to hell since the harmful activities of his wealthy neighbour have enormous economic benefits because of the utility of his neighbour's undertaking. There must be an intentional, balanced approach to weighing economic activities and their far-reaching negative environmental implications on other stakeholders.

27 ibid 667. 
The position adopted by the court is hinged on the "pollute first, control later" philosophy of economic growth and development. ${ }^{28}$ Most developed countries of Europe and US adopted this approach in their pursuit of economic development. China has also followed suit, but with dire implications on the state of the human environment. ${ }^{29}$ Could it be rightly stated that the pursuit of economic development and environmental protection are two sides of the same coin, since they both espouse anthropocentric innovativeness?

In the early 70s case of Boomer v. Atlantic Cement $\mathrm{Co}^{30}$ with facts similar to the above case, it was similarly decided that the polluting company make a one-time payment of permanent damages instead of granting an injunctive relief against the polluters. The court further stated that the scope of the problem was beyond the capacity of courts to settle through determination of private suits. In other words, the American courts have been so careful not to formulate environmental policies for the nation through their decisions; they would rather reserve that for the legislature. ${ }^{31}$

The decision of the U.S. Supreme Court in Hadacheck v. Sebastian ${ }^{32}$ presents another good example of the clash of these rights. Hadacheck was into brick making, which he had undertaken for years, but his trade had been producing "fumes, gases, smoke, soot, steam and dust ... [which] from time to time caused sickness and serious discomfort to those living in the vicinity." There was no doubt as to his having engaged in this trade long before the neighbours settled in the neighbourhood. ${ }^{33} \mathrm{~A}$ conflict arose only when others

28 A. Wang, 'The Role of Law in Environmental Protection in China: Recent Developments' (2007) 8 Vermont Journal of Environmental Law 199.

29 ibid.

3026 N.Y. 2d 219, 257 N.E. 2d 870 (N.Y 1970).

31 D. R. Hodas, "Biodiversity and Climate Change Laws: A Failure to Communicate?" 3rd Colloquium of the IUCN Academy of Environmental Law (10 -15 July 2005 at Macquarie University Sydney, Australia) <http://ssrn.com/abstract $=$ 1549846> accessed 31 March 2016.

32239 U.S. 394 (1915).

33 Under the province of the law of tort, coming to tort is no defence that could avail a defendant who is engaged in harmful economic activities. In Bliss $v$ Hall (1838) 4 Bing. N.C 183, the defendant had been operating a tallow-chandlery which emitted "divers noisome, noxious, and offensive vapours, fumes, smells, and stenches" to the discomfort of the plaintiff, who had settled near it a few years after the operations had commenced. The court held to be no defence that the existence of the business had preceded the coming to such neighbourhood by the plaintiff because he "came to the house ... with all the rights which the common law affords, and one of them is the right to wholesome air". See WVH Rogers, Winfield and Jolowicz Tort (18th Edn, Sweet and Maxwell, London 2010) 746. 
started moving into the area. The million-dollar question then was: did his first use of the atmosphere as a depository for the noxious by-products of his brick-making operation give him a "right" to pollute? It was held that Hadacheck's first use did not create a "right"; it violated a "duty", which the public had a "right" to enforce.

As earlier pointed out, the 1999 Constitution of the Federal Republic of Nigeria ${ }^{34}$ and the Petroleum Act, ${ }^{35}$ exclusively vest the ownership of oil, gas and all minerals on or under any land which forms part of Nigeria or its exclusive economic zone on the federal government. It is without doubt that it is this level of government that has the absolute ownership right over petroleum and related resources in Nigeria. With this right comes the power to explore all direct and associated advantages relating to same, and presumably for the benefit of the public. This is usually exercised through the engagement of IOCs, which have the requisite expertise and wherewithal to explore and exploit these resources. This takes the form of operational agreements of various forms which basically include: concession ${ }^{36}$ (the concession period abated with Nigeria's membership of Organisation of Petroleum Exporting Countries (OPEC) in 1971); production sharing contracts ${ }^{37}$ - a contract for the development of mineral resources under which the contractors' costs are recoverable each year out of the production but there is a maximum amount of the production which can be applied to this cost

34 Section 44 (3) thereof.

35 Section 1.

36 This is a grant of a property right in minerals, usually for a very long period. The investor has an almost complete property right in the minerals in the ground, that is to say all the interest but the bare legal title. See CJ Lipton, "Negotiation and Drafting of Mining Development Agreements". Paper presented at Interregional Workshop organised by the UN. Bueno Aires Mining Journal Books Ltd. (London) 1986 p. 92, quoted in MM Gidado, Petroleum Development Contracts with Multinational Oil Firms: The Nigerian Experience (Ed-Linform Services, Maiduguri 1999), p. 112.

37 This is an arrangement whereby the contracting State (while retaining the ownership right over the mineral) engages an IOC to prospect for oil in a defined area and such IOC (relying on its technical skills), bears the financial risk of such undertaking, save oil is found in commercial quantity. Where oil is found, the IOC pays royalty (in oil), takes cost oil value (being the cost of the prospecting and production), then what is left (profit oil) is shared in a predetermined ratio between the parties. Finally, the IOC finally income tax on its share of the profit oil. See Allen and Overy, "Guide to Extractive Industries Documents - Oil and Gas" (2013) World Bank Institute Governance for Extractive Industries Programme 2-3. <wbi.worldbank.org/.../World\%20Bank\%20Extractive\%20 Industries\% 20...> accessed 2 August 2014. 
recovery in any one year. ${ }^{38}$ Also included are Joint Venture Agreements (JVAs) ${ }^{39}$ and service contracts. ${ }^{40}$ Under the service contract, a host government must have the requisite technological know-how and access to capital..$^{41}$ This is based on the premise that the oil producing country needs three services from the IOC, technical, financial and commercial ability. ${ }^{42}$

The paper proceeds to discuss whether the right of the lessee or "tenant" to undertake petroleum operations start and end with exploiting the advantages of such right notwithstanding the associated responsibility relating to the environment?

\section{PROPERTY RIGHTS AS HUMAN RIGHTS}

One of the fundamental requirements of a capitalist economic system is a strong system of property rights. For decades, social critics in the United States and throughout the Western world have complained that property rights too often take precedence over human rights, with the result that people are treated unequally and have unequal opportunities. Property rights are human rights. ${ }^{43}$

Property right over a piece of land, a coalmine, or a spring creek consists of control over that resource. An important feature of a property right is the ability to exclude others from using the resource. The right to use, but not to exclude others from use, would be a highly imperfect (or ill-defined) property right. In addition, Douglass North has posited that, in effect, "one cannot develop a useful analysis of the state divorced from property rights." ${ }^{4}$

38 HR Williams and CJ Meyers, Oil and Gas Law (Mathew bender, New York 1966) 686, quoted in Gidado (n 36), p. 158.

39 This is a partnership-based approach, under which the foreign company does business with a State-owned company, which represents the host government. The venture may involve creating a jointly controlled project company. This approach centres on the decision of the host country to share in the "ownership and control over operation in their oil industries" - see M Likosky, "Contracting and Regulatory Issues in the Oil and gas and Metallic Minerals Industries" (2009) 18 (1) Transnational Corporations 13.

40 Under this arrangement, Government seeks to exert greater control over the exploration and exploitation of its resources. It may do this through service contracts, whereby private companies are brought in to accomplish carefully delineated tasks.

41 ibid 14.

42 Gidado (n 36) 174.

43 A. A. Alchian (n 22).

44 D. North, "A Framework for Analysing the State of Economic History" (1979) 16 Explorations in Economic History 249-259, quoted ibid. 
In historical terms, recognition and protection of property rights have been considered one of the indispensable pillars of industrial revolution. Acemoglu and Robinson have argued concerning the Industrial Revolution in England that:

The Industrial Revolution was manifested in every aspect of the English economy. There were major improvements in transportation, metallurgy, and steam power... This dynamic process was unleashed by the institutional changes that flowed from the Glorious Revolution ... It was about a fundamental reorganisation of economic institution in favour of innovators and entrepreneurs, based on the emergence of more secure and efficient property rights.

Improvement in the security and efficiency of property rights, for example, played a central role in the "transportation revolution", paving the way for Industrial Revolution. ${ }^{45}$

From the foregoing, the right to, and interest in property must be legally protected, as one of the cardinal pillars in a market economy in order to guarantee economic growth and development. Within the Nigerian domestic legal domain, this right has found constitutional recognition as a fundamental right. ${ }^{46}$ Where this right is infringed upon, it gives rise to a cause of action against the culprit, even if it is the government. ${ }^{47}$ Furthermore, where the government compulsorily acquires the property of another, it is required to do so with regards to the due process of the $\operatorname{law}^{48}$ and to pay adequate compensation. ${ }^{49}$

45 D. Acemoglu and J. A. Robinson, Why Nations Fail (Profile Books Ltd., London 2012), 197.

46 Sections 43 and 44 of the 1999 Constitution of the Federal Republic of Nigeria. 47 See sections 6 (a) and (b) and 43 and 44 of the 1999 Constitution of the Federal Republic of Nigeria (as Amended).

48 The Supreme Court while setting aside the decision of the Nigerian Federal Government to compulsorily acquire 50\% stake in Oil Mining Lease 217 granted the respondents held per Vivour-Rhodes, JSC in NNPC \& Anor. v. Famfa Oil Ltd. (2012) LPELR-7812 (SC) (Consolidated) thus: The Federal Government of Nigeria has a right to a participating interest of 50\% in OML 127 (and indeed in any OML). In the light of the fact that there was non-compliance by the Minister of Petroleum with the clear provisions of Paragraph 35 of the First Schedule of the Petroleum Act, the acquisition by the Federal Government of Nigeria in OML 127 was illegal and unconstitutional. It offends section 44 (1) of the Constitution. 49 Section 44 (a). 


\section{THE NATURE OF ENVIRONMENTAL "HUMAN RIGHTS"}

Environmental right issues are still very contentious; ${ }^{50}$ there is no generally acceptable definition of environmental law because it is inarguable that most of the central concerns of this emerging discipline are contested. ${ }^{51}$ Similarly, there is no consensus on the substance and province of environmental rights. ${ }^{52}$

To situate environmental rights within the established domestic legal framework in operation in a country like Nigeria, it is obvious that the right to a healthy environment cannot be ascribed a "fundamental right" depiction. Section 20 of the 1999 Constitution provides that "[T] he State shall protect and improve the environment and safeguard the water, air and land, forest and wild life of Nigeria." However, the same constitution further provides in section 6 (6) (c) that all rights under the Fundamental Objective of State Policy (chapter 2) of the Constitution are non-justiciable. This makes it a mere persuasive provision without more.

The African Charter on Human and Peoples Rights however makes provision for binding right to healthy environment in its article 24. It provides that "[A]ll peoples shall have the right to a general satisfactory environment favourable to their development." ${ }^{33}$ The problem with enforcing this provision of the Charter before Nigerian courts, even though domesticated, is that its sting has been tamed by section 6(6) (c) of the constitution earlier considered. That makes this right non-justiciable before Nigerian courts. The only option

50 There is an argument that there are three variants of this right claim: right to a satisfactory environment, the right of the environment and environmental right. See KSA Ebeku, "The Right to a Satisfactory Environment and the African Commission" (2003) 3 African Human Rights Law Journal 150; LE RodriguezRivera 'Is the Human Right to Environment Recognised Under International Law? It Depends on the Source' (2001) 12 Colorado International Law and Policy 1.

51 S. Bell and D. McGillivray, Environmental Law (7th Edn, Oxford University Press, London 2008) 6.

52 There are basically two schools of thought on whether environmental rights claims have the status of right ascribable to human beings.

53 Communication 155/96, The Social and Economic Rights Action Center and the Center for Economic and Social Rights/Nigeria (delivered at its 30th session held in Banjul, The Gambia from 13th to 27th October 2001) <www.achpr.org> accessed 12 August 2010. 
a victim has is to approach the African Commission..$^{54}$ In the case of SERAC $v$. Nigeria,${ }^{55}$ the African Commission assumed jurisdiction, citing its earlier decisions, ${ }^{56}$ in this matter despite the complainants' inability to exhaust local remedies requirement, which is intended to give the domestic courts an opportunity to decide upon cases before they are brought to an international forum. ${ }^{57}$

The African Commission declared that Nigeria had breached its obligations to respect, protect, promote, and fulfil rights guaranteed by the African Charter. Among other violations, Nigeria was found culpable of violating rights guaranteed under articles 22 (right of the people to freely dispose of their wealth and natural resources) and article 24 (the right of peoples to a "general satisfactory environment favourable to their development").

The Commission declared further that the right to a general satisfactory environment, as guaranteed under Article 24 of the African Charter or the right to a healthy environment, as it is widely known, therefore imposes clear obligations upon government. It requires the State to take reasonable and other measures to prevent pollution and ecological degradation, to promote conservation, and to secure an ecologically sustainable development and use of natural resources. The Commission found the Federal Republic of Nigeria to be in violation of Articles 2, 4, 14, 16, 18(1), 21 and 24 of the African Charter, and appealed to it to ensure the protection of the environment, health and livelihood of the people of Ogoniland by investigating and prosecuting government officials and the state-owned Nigerian National Petroleum Corporation (NNPC) for any form of violation of human rights. ${ }^{58}$ The Nigerian state has not taken any action since the decision was made over a decade ago, and no sanction of whatever nature has been meted on it till date.

Historically, the clamour for environmental rights and its protection was reactive to the evolving and unmitigated damage to the environment as a result of the emanating negative impacts of human and economic activities

54 As undertaken in SERAC v. Nigeria (Case No. Achpr/Comm/ A044/1. African Commission On Human And Peoples' Rights, May 27, 2002). The further problem a successful litigant would have would be with enforcement of any award granted by the Commission. Findings of the commission are merely advisory and lack any force of law.

55 ibid.

56 Communications 25/89, 47/9 0, 56/9 1, 100/9 3, World Organisation Against Torture et al. /Zaire; Communication 60/9 1Constitutional Right Project/Nigeria and Communication 101/9 3 Civil Liberties Organisation/Nigeria.

57 ibid paragraph 38.

58 SERAC $v$. Nigeria (n 54). 
on the state of the environment. The late 1960s and the early 1970s witnessed the most clamour for the creation of normative structures that could remediate preceding harms on the environment and curb the present activities and the future impact of human activities on the earth, or, as some are wont to call it, "the commons" or "unowned" environment.

There have been arguments about where to situate environmental human right. Three arguments have surfaced in this regard:

1. That it be accorded an independent (stand-alone) recognition as human right; or

2. That it should be interpreted as having legal recognition within the existing human rights;

3. Environmental rights are considered as rights of the environment in and of itself, regardless of its effects on people. ${ }^{59}$

4. Procedural environmental right.

\subsection{Independent (Stand-Alone) Right}

This conceives human right as an independent right, just like the right to life, right to own property, right to freedom of speech, among other rights. This means legal burden bearers are established and the beneficiaries are also clearly defined. The African Charter in article 24, for instance, accords a collective right to healthy environment to peoples and not individual members of society. However, there are scholars who hold the view that the province of human rights has been saturated and has fully matured; hence, there is no opening for new concepts of human right to be accommodated. The humanrightism ("individualistic" perspective) popularised by Pellet, ${ }^{60}$ for instance, considers human rights as a self-concluded discipline situated within the province of formal international standards hinged on its traditional doctrine of human rights as rights of the individual and not that of the community. ${ }^{61}$

Human rights are indisputably a growing concept. Every generation finds a way to secure more freedom from state domination or interference whether within or without a state setting. This demonstrates the gradual growth of

59 J. Cassel, "Enforcing Environmental Human Rights: Selected Strategies of US NGOs" (2007) 6(1) Northwestern Journal of International Human Rights, p. 104.

60 "Human Rightism' and International Law" (2001) X Italian Yearbook of International Law 3, quoted in F Francioni, "International Human Rights in an Environmental Horizon" (2010) 21 (1) The European Journal of International Law, p. 54.

61 ibid. 
the generations of human rights. The stimulus for the first generation of rights struggle was the need for freedom from state cruelty and its overbearing influence on citizens' engagements inter se. The second generation of rights came about to make governments responsible to the needs of the people by way of education, and socio-economic wellbeing.

The third generation, to which environmental rights claim is conveniently situated, is hinged on collective claim of a people or group. For instance, the right to self-determination was first recognised as such in the two central UN human rights treaties of 1966: the International Covenant on Economic, Social and Cultural Rights and the International Covenant on Civil and Political Rights. One example of this conception is found in Article 11 of the San Salvador Protocol to the American Convention on Human Rights, which was adopted in 1988 and entered into force in November 1999. Article 11(1) states "[e]veryone shall have the right to live in a healthy environment and to have access to basic public services." It has been noted that 60 per cent of the approximately 193 countries of the world have their constitutions mention the protection of the environment or natural resources. ${ }^{62}$ One hundred and nine of them recognise the right to a clean and healthy environment and/or the state's obligation to prevent environmental harm. ${ }^{63}$ Of these, 56 constitutions explicitly recognise the right to a clean and healthy environment, and 97 constitutions make it the duty of the national government to prevent harm to the environment. ${ }^{64}$

\subsection{Legal Recognition within the Existing Human Rights Province}

It has also been argued that the right to life and other first generation rights would make no meaning if the right to a safe environment were not guaranteed. This is because, where the human environment is contaminated, it affects the quality of human life or life expectancy hence an infringement on the fundamental right to life. In the case of India, for instance, the constitution does not apparently create an enforceable right to a healthy environment but, unlike the EU Charter, it has encouraged Indian courts to give other human rights, including the right to life, a very vigorous environmental interpretation.

62 Earth Justice, "Environmental Rights Report: Human Rights and the Environment." Materials for the 67th Session of the UNCHR (Geneva, March 14-April 22, 2005).

63 ibid.

64 ibid. 
The result has been a jurisprudence which uses human rights law to address questions of environmental quality, more than in any other country. ${ }^{65}$

\subsection{Right of the Environment}

The third claim is hinged on the right of the environment itself, distinct from the right of human beings to a clean and satisfactory environment. This claim in itself raises quite a number of posers: does the "environment" exist as a legal entity capable of enjoying a "right" just like the human being? In this case, who then bears the burden of recognising and enforcing such right? This question has however found answer in some jurisdictions, including Kenya where this right is protected via public interest litigation undertaken by interested persons, especially civil society organisations on behalf of the environment.

\subsection{Procedural Environmental Right}

Procedural environmental right is emphasised in environmental agreements relating to access to information on environmental issues, public participation and access to judicial and administrative redress mechanism. ${ }^{66}$ The most visible among international agreements, which emphasises procedural human rights to achieve better environmental protection, is the Convention on Access to Information, Public Participation and Access to Justice in Environmental Matters, (Aarhus, 25 June 1998). ${ }^{67}$ This entails a form of community access to information and to the means to participate in decisions which affect the quality of their local environment." ${ }^{18}$

65 A Boyle, "Human Rights and Environment: A Reassessment" (2010) $<$ www.unep.org/environmentalgovernance/Portals/8/documents/Human RightsEnvironmentRev.pdf> accessed 27 July 2014.

66 D Shelton, "Human Rights, Health and Environmental Protection: Linkages in Law and Practice" (2007) 1. Human Rights and International Legal Discourse $11,14-15$.

67 ibid 15.

68 National Environmental Justice Advisory Council (NEJAC) "Meaningful Involvement and Fair Treatment by Tribal Environmental Regulatory Programs" (2004) 5 quoted in RT Akoh, "Nigeria's Land Use Act: An Anti-Thesis to Environmental Justice" (2009) 53 (2) Journal of African Law, 291. 


\section{IMPACT OF OIL AND GAS POLLUTION ON ENVIRONMENT AND HUMAN HEALTH}

\subsection{Oil Spillage}

Between 1976 and 1996, 647 incidents of oil spillage were reported, resulting in the spill out of 2,369,407.04 barrels of crude oil, out of which 549,060.38 barrels were recovered and the remaining 1,820,410.50 barrels of oil were lost to the ecosystem. ${ }^{69}$ Oil contains harmful chemicals in varying degree, depending on its source. Some of these chemicals, which are harmful to humans, the flora and the fauna, in the event of spillage or durable exposure include sulphur, benzene, and polycyclic aromatic hydrocarbons (PAHs). ${ }^{70}$ It has also been established that exposure to some crude oil components cause respiratory, hepatic, renal, endocrine, neurologic, hematologic, or other systemic effects, and single molecular DNA alteration, among other ailments. PHAs potentially cause skin and lung cancer and have reproductive and developmental toxic effects. ${ }^{71}$ In the same vein, oil vapours have been found to cause headaches, dizziness, nausea, vomiting, eye and throat irritations, as well as breathing difficulties. Large quantities of these vapours expose people to the danger of chemical poisoning called hydrocarbon pneumonia. ${ }^{72}$

\subsection{Gas Flaring}

Nigeria is reputed to be the world's biggest offender in associated gas flaring. ${ }^{73}$ By flaring associated gas, methane and carbon dioxide are released into the atmosphere. These two chemicals have been identified as two of the six most potent greenhouse gases recognised under the Kyoto protocol. ${ }^{74}$ The environmental problems caused by flaring are mainly global, but to some

69 O. M. Ajide and O. O. Isaac, "An Assessment of Physical Impact of Oil Spillage Using GIS and Remote Sensing Technologies: Empirical Evidence from Jesse Town, Delta State, Nigeria" (2013) 12 (2) British Journal of Arts and Social Sciences, 235.

70 B. D. Goldstein, et al, "The Gulf Oil Spill" (2011) 364 (14) The New England Journal of Medicine, p. 1335.

71 US Department of Health and Human Services, "Toxicological Profile for Polycyclic Aromatic Hydrocarbons (PAHs): quoted ibid.

72 A. Salako et al, "Oil Spills and Community Health: Implications for Resource Limited Settings" (2012) 4 (9) Journal of Toxicology and Health Sciences, p. 147.

73 This is natural gas that is found together with oil in the same reservoir as a cap of gas above the oil or dissolves into the crude oil. See 2B1st Consulting, "Natural gas" < www.2b1stconsulting.com/associated-gas/> accessed 31 July 2014.

74 Others are sulphur hexafluoride, hydrofluorocarbons, perfluorocarbons, nitrous oxide. See the Kyoto Protocol, Annex A. 
extent also regional and local. For example, flaring/venting during oil production operations emits $\mathrm{CO}_{2}$, methane and other forms of gases which contribute to global warming and, by implication, climate change, and this affects the environmental quality and has far- reaching consequences on the health of human beings and biodiversity of the surrounding aea of the flare. ${ }^{75}$

According to Augustine, ${ }^{76}$ Nigeria has had regulations in the books banning gas flaring for decades, but has not succeeded in effectively implementing them. At least four decades ago, in 1969, the Nigerian government promulgated a law, ${ }^{77}$ mandating oil companies to set up infrastructure for the use of the associated gas within five years of the commencement of oil production. ${ }^{78}$ The government also enacted the Associated Gas Reinjection Act in 1979, which penalised the continuous flaring of gas five years from the date of the legislation. The fine for gas flaring was also raised from N0.5 to N10 for every $1,000 \mathrm{ft}^{3}$ of gas flared in 1998, but this fine is still too low to have an impact on these companies' policy toward gas flaring. ${ }^{79}$

Medical research has further shown that gas flaring forms part of the basis of low life expectancy age in the Niger Delta region that is pegged at 43 years. Similarly, in the Niger Delta, 12 per cent of new born babies do not survive their first birthday. ${ }^{80}$ In the same vein, gas flaring has been established to have caused the local communities diseases like cancers, asthma, chronic

75 O. S. Ismail and G. E. Umukoro, "Global Impact of Gas Flaring" (2012) 4 Energy and Power Engineering 29.

76 O. I. Augustine and W. W. Sanford, "The Effects of Waste Gas Flares on the Surrounding Vegetation in South-Eastern Nigeria" (1976) Vol. 13, No. 1 Journal of Applied Ecology, 177-187 quoted ibid.

77 Section 43 of the Petroleum Act, 1969 provides that "[N]ot later than five years after the commencement of production from the relevant area, the licensee or lessee shall submit to the Minister any feasibility study, programme or proposals that he may have for the utilisation of any natural gas, whether associated with oil or not, which has been discovered in the relevant area."

78 B. Manby, Shell in Nigeria: Corporate Social Responsibility and the Ogoni Crisis (New York: Carnegie Council on Ethics and International Affairs), pp. 1-2.

79 M. Ishisone, "Gas Flaring in the Niger Delta: The Potential Benefits of its Reduction on the Local Economy and Environment" $4<$ http://nature.berkeley. edu/classes/ es196/projects/2004final/Ishone.pdf> accessed 06 April 2016.

80 "Environmental Racism: The Gas Flares that Bring Death and Destruction to Nigeria" $2<$ www. elombah.com/index.php?option=com_content\&view $=$ article\&id=3447:enviromental-racism-the-gas-flares-that-bring-death-anddestruction-to-nigeria\&catid $=30$ :the-economy\&Itemid $=4>$ accessed 5 July 2010. 
bronchitis, blood disorders, and others. ${ }^{81}$ Even the IOCs acknowledge without a corresponding action, their failure to achieve own gas flaring reduction targets. ${ }^{82}$

\section{PROPERTY RIGHT VERSUS ENVIRONMENTAL HUMAN RIGHTS}

There must be a form of equilibrium between oil operations and environmental protection (sustainable development). In the seventeenth century, John Locke sought to balance the commons and private property conflicting interest. ${ }^{83}$ He saw that private property does not exist independent of other variables; it exists in relationship to the commons. Despite the justification that private property boosts economic production, the commons functions to provide sustenance for all. Locke believed that God gave the earth to "mankind in common," but that private property is justified because it spurs humans to productive activity or work. Whenever a person mixes his labour with nature, he "joins to it something that is his own, and thereby makes it his property." 84

Locke added an important proviso: "For this labour being the unquestionable property of the labourer, no man but he can have a right to what that is once joined to, at least where there is enough, and as good, left in common for others." In other words, a person can acquire property, but there's a limit to how much he or she can rightfully appropriate without leaving anything to others. ${ }^{85}$ This similarly brings us to the issue of collective property as discussed above. The right of the "owner" of such property is not absolute; it is subject to the overriding interest of society over how such property is utilised, just like the scenario of the owner of a historic building referred to above.

81 Environmental Rights Action/Friends of the Earth Nigeria, Fact Sheet: Harmful Gas Flaring in Nigeria (2008) 2 <www.foe.org/pdf/GasFlaringNigeria-_FS.pdf > accessed 1 July 2010.

82 Shell in 2013 reports that it globally reduced the quantum of gas it flared in the cause of its oil operations from 7.7. million to 7.4 million tonnes of $\mathrm{CO} 2$ equivalent. Interestingly it noted that it was due to decrease in their production and not because of any conscious activity undertaken for the purpose of reducing even their own flaring targets. See Shell, Sustainability Report: Royal Dutch Shell Plc Sustainability Report 2013, 33 < http://reports.shell.com/sustainability-report/ 2013/our-activities/nigeria/operations-in-2013.html> accessed 6 April 2016.

83 P. Barnes (n. 4) 16.

84 ibid.

85 ibid. 
In the Maya Indigenous Community of Toledo Case,${ }^{86}$ for instance, the Inter American Commission on Human Rights, citing the case of SERAC $v$. Nigeria, ${ }^{87}$ concluded that there had been violations of the petitioners' right to property in their ancestral land. It reiterates that "development activities must be accompanied by appropriate and effective measures to ensure that they do not proceed at the expense of the fundamental rights of persons who may be particularly and negatively affected, including indigenous communities and the environment upon which they depend for their physical, cultural and spiritual well-being." $" 88$

From the above classification of property ownership types, the federal government's right over petroleum and natural resources in Nigeria can best be classified as state property, which is an offshoot of collective property ownership; the interest of IOCs over petroleum resources in the region can best be viewed in the same light of "collective property". This entails that the right of the IOCs is subject to the overriding interest of other stakeholders, including host communities. In this event, reliance on their "right" to operate, where it results in pollution, can be put on halt in the interest of other stakeholders, especially when placed against the implications of pollution on human health, biodiversity and the resultant climate change. This is further hinged on the premise that the right to life is not only infringed upon by death of the beneficiary, but where life-threatening harm is caused a person, that is enough infringement on their right to life, ${ }^{89}$ which should warrant legal redress. When people's source of livelihood: farmlands, drinking water sources, etc., are polluted, their right to life is in no less manner infringed upon.

In Nigeria, it is indisputable that neither the right to a healthy environment nor the right of the environment are fundamental rights. Consequently there is a need for an expounded reading of constitutional provisions ${ }^{90}$ on the province of the right to life to protect the right to a safe environment as have been adopted in other climes like India.

86 Maya indigenous Community of the Toledo District v. Belize, Case 12.053, Report No. 40/04, Inter-Am. C.H.R., OEA/Ser.L/V/II.122 Doc. 5 rev. 1, 727 (2004) quoted in A Boyle, "Human Rights and the Environment: A Reassessment" (2010) Boyle UNEP Paper Revised.

87 SERAC v. Nigeria (n 54).

88 ibid.

89 P. Stephens, "Applying Human Rights Norms to Climate Change: The Elusive Remedy", Vermont Law School Legal Studies Research Series, No. 10-46 < http:/ /ssrn.com/abstract $=1645346>$ accessed 30 July 2010.

90 Section 33 (1) of the Constitution of the Federal Republic of Nigeria 1999 (as amended) on right to life. 


\section{CONCLUSION}

The right to explore and exploit petroleum resources in Nigeria must be founded on the "collective property" theory and not the private property concept on which the IOCs base their claim. The Oil Prospecting Licence (OPL), Oil Exploration Licence (OEL) and Oil Mining Lease (OML), granted IOCs, which confer on them the right to prospect for, explore or mine petroleum resources under the Petroleum Act ${ }^{91}$ do not purport to grant them the right to pollute the environment as well. It is beyond doubt that the unsavoury environmental implications of the operations of Multinational Corporations in general and IOCs in particular, in the developing countries leave much to be desired. Their commitment to environmental rights protection and human rights is far below what they profess and observe in territories with strong legal framework and functional enforcement mechanism. They subscribe to endless operational documents as basis for their operations but compliance does not go beyond the papers on which such documents are printed. ${ }^{92}$

91 Section 2 of the Petroleum Act, Cap P 10, Laws of the Federation of Nigeria, 2004.

92 See UN Human Rights Council his Guiding Principles on Business and Human Rights: Implementing the United Nations "Protect, Respect and Remedy" Framework (Ruggie Principles), Sullivan Principles, OECD Principles, etc. 